\title{
URINARY EXCRETION OF HYDROXYPROLINE AND ACID PHOSPHATASE IN RELATION TO EGG-SHELL FORMATION IN THE DOMESTIC FOWL
}

\author{
K.-M.-L. MORRIS $\left({ }^{1}\right)$ and T.-G. TAYLOR $\left({ }^{2}\right)$ \\ Department of Physiology and Biochemistry, \\ The University, Reading (Great-Britain)
}

\section{INTRODUCTION}

The urinary excretion of hydroxyproline, the bulk of which arises from collagen, has been increasingly used as an index of the turnover of bone matrix (ZiFF et al., I956; DUli and Henneman, I963; KLEIN et al., I964), but no data for the domestic fowl have been published. The latter is true also for the urinary excretion of acid phosphatase, which, together with other lysosomal acid hydrolases, is probably concerned with bone resorption (VAES, I965).

Skeletal metabolism in the laying hen is extremely active, and throughout the reproductive period, which lasts for many months, secondary bone grows from the endosteal surfaces of many bones to form a fine interlacing network of trabeculae known as medullary bone. Growth of medullary bone is stimulated by the combined action of cestrogen and androgen and is probably continuous. Breakdown of medullary bone is intermittent and is associated with the calcification of the egg-shell. (See Simkiss, 1967 , for a review of the role of medullary bone in egg-shell formation).

Urinary hydroxyproline excretion reflects the rate of both the destruction and the formation of collagen, since it is derived from the breakdown of mature collagen fibres and of newly synthesized tropocollagen before cross-linkage to form insoluble collagen has occurred (KLEIN et al., I964; PROcKOP, I964). Since the period of rapid bone resorption is well defined in the hen in relation to the calcification of the shell it was considered that a study of the urinary excretion of hydroxyproline might define more precisely the relative contribution of the two processes.

(1) Present address : Barking Regional College of Technology, Dagenham, Essex (Great-Britain).

(2) Present address : Departement of Physiology and Biochemistry, The University, Southampton, SO 95 NH (Great-Britain). 


\section{EXPERIMENTAL}

\section{Urine collections}

Twenty four-hour samples of urine were collected from hens (Messrs. Thomber 404) weighing I.7-2.2 kg which had been laying for 2 years and which had been colostomized by the method of FUSSELl (1960) at about 8 months of age. They were fed a commercial layers' diet, containing approx 3 p. Ioo calcium. Urinc samples were collected every three hours and the samples were bulked and stored in a refrigerator at $2^{\circ} \mathrm{C}$. Samples were then centrifuged to remove urates and the final volume was measured.

Since the birds were laying mainly single-egg clutches it was possible to analyse urine samples collected successively on a laying day, during the post-lay $24 \mathrm{~h}$ (when no further egg-shell was being calcified) and on a non-laying day (encling at least ${ }^{8} \mathrm{~h}$ after an oviposition). On laying days urine collections began when a soft egg entered the shell-gland (determined by regular palpation) and on non-laying days at $\mathrm{I} 6.00 \mathrm{~h}$, by which time, if no egg were present in the shellgland, it was fairly certain that the bird would not lay on the following day. This was checked by further palpation at $22.00 \mathrm{~h}$. In a second experiment, designed to investigate the excretory pattern of hydroxyproline, four 6-h collections were made from seven birds on laying and nonlaying days.

\section{BIOCHEMICAI，DE'TERMINATIONS}

\section{Total hydroxyproline}

Duplicate I $\mathrm{ml}$ samples of urine were hydrolyzed with $6 \mathrm{~N} \mathrm{HCI}$ for three hours at $120^{\circ} \mathrm{C}$ in sealed tubes, the final volume being $7 \mathrm{ml}$. The hydrolysates were evaporated to dryness on a water bath $\left(60^{\circ} \mathrm{C}\right)$ and the residue taken up in $5 \mathrm{ml}$ o.ooI N HCI. After centrifugation (2000 $\mathrm{g}$ for so min) hydroxyproline determinations were carried out by the method of BERGMan and LOXLEY (I963). Sample blanks wers included because of the brown colour of many of the hydrolysates.

\section{Acid phosphatase}

The method of BeLl and SILLER (1962) for the determination of acid phosphatase in plasma was used. The tubes were centrifuged (2000 $g$ for $5 \mathrm{~min}$ ) immediately before the colours were read.

\section{RESULTS}

Urinary excretion of hydroxyproline on laying days was approximately twice that on both non-laying days and on days immediately following the laying of an egg (table I). When the 24 hour collection was made up of four 6 -hour samples a dictinct pattern for hydroxyproline excretion became evident on laying days (table 2 ), the bulk of the extra hydroxyproline being excreted in the period 6-I 8 hours after the start of shell formation.

Urinary acid phosphatase levels were nearly four-times greater on laying than on non-laying days and on days immediately following the laying of an egg (table $\mathrm{I}$ ) There was a highly significant positive correlation $(r=+0.7 \mathrm{I}$, significant at 


\section{TABI,E I}

Urinary excretion of total hydroxyproline

$(\mathrm{mg} / 24 \mathrm{hr}$ ) and of acid phosphatase ( $\mu$ moles substrate hydrolysed/hr) in hens (means of 9 birds \pm S. E.) for laying and non-laying days

\begin{tabular}{|c|c|c|c|}
\hline & $\begin{array}{c}\text { Non-laying } \\
\text { (no shell formation) }\end{array}$ & $\begin{array}{c}\text { Laying } \\
\text { (shell formation) }\end{array}$ & $\begin{array}{c}\text { After laying } \\
\text { (no shell formation) }\end{array}$ \\
\hline \multirow{3}{*}{ Hydroxyproline } & $4.0 \epsilon_{\mathrm{k}}$ & $8.58(1)$ & 4.73 \\
\hline & \pm 0.79 & 0.94 & \pm 0.37 \\
\hline & 34.1 & $118.7\left({ }^{2}\right)$ & 33.0 \\
\hline Acid phosphatase $\ldots$ & \pm 6.4 & $\pm \quad 8.5$ & \pm 7.8 \\
\hline
\end{tabular}

(1) Significantly greater than means for non-laying and after laying ( $P<0.01$, paired ' $t$ ' test).

(') Significantly greater than means for non-laying and after laying $(\mathrm{P}<0.001$, paired ' $t$ ' test)

\section{TABLE 2}

Urinary excretion of total hydroxyproline (mg) in 6-hr periods for laying and non-laying hens (means of 7 birds \pm S. E.). Egg enters shell-gland at zero hour and shell calcification ends $20 \mathrm{hr}$ later

\begin{tabular}{|c|c|c|c|c|c|}
\hline & \multicolumn{4}{|c|}{ Hours } & \multirow{2}{*}{$\begin{array}{l}24 \mathrm{hr} . \\
\text { Total }\end{array}$} \\
\hline & $0-6$ & $6-12$ & $12-18$ & $18-24$ & \\
\hline Laying ... & $\begin{aligned} & 1.91\left(^{1}\right) \\
\pm & 0.42\end{aligned}$ & $\begin{aligned} & 2.73\left(^{(2)}\right. \\
\pm & 0.38\end{aligned}$ & $\begin{aligned} & 3.60\left(^{2}\right) \\
+ & 0.26\end{aligned}$ & $\begin{aligned} & 1.53\left(^{(1)}\right. \\
+ & 0.17^{(1)}\end{aligned}$ & 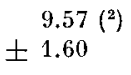 \\
\hline Non-laying & $\begin{array}{r}0.91 \\
\pm \quad 0.03\end{array}$ & $\begin{array}{r}1.01 \\
\pm 0.05\end{array}$ & $\begin{array}{r}1.17 \\
\pm 0.11 t\end{array}$ & $\begin{array}{r}0.90 \\
\pm 0.06\end{array}$ & $\begin{array}{r}3.99 \\
\pm 0.66\end{array}$ \\
\hline
\end{tabular}

(1) Significantly greater than corresponding mean on non-laying days ( $\mathrm{P}<0.05$ paired ' $t$ ' test)

( $\left.{ }^{2}\right)$ Significantly greater than correspondnig mean on non-laying days $(\mathrm{P}<0.001$ paired ' $t$ ' test)

$\mathrm{P}<0.001)$ between the amounts of hydroxyproline and acid phosphatase excreted in the urine during 24 hours periods (fig. I). The regression equation relating the two variables was

where $y=\mathrm{mg}$ hydroxyproline.

$$
y=0.049 x+2.93
$$

$x=\mu$ moles acid phosphatase substrate hydrolyzed/hour. 


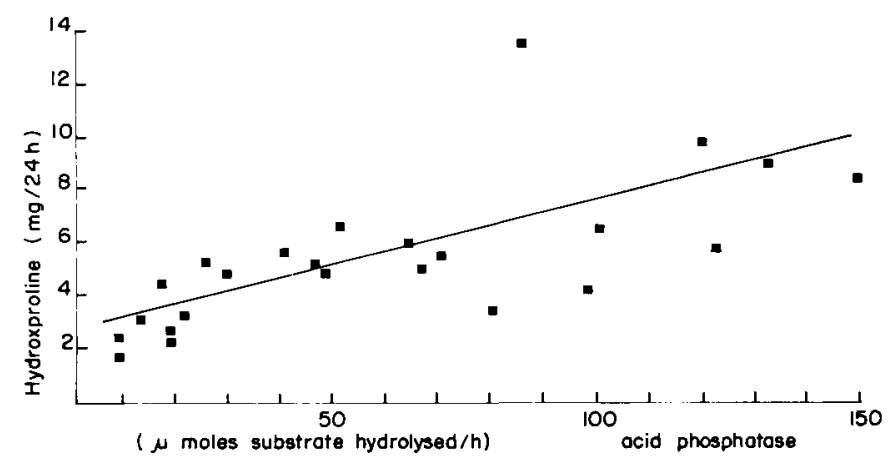

FIG. I. - Relationship between the amounts of hydroxyproline and acid phosphatase excreted in the urine of hens during $24 h$ periods Each point represents one hen-day

\section{DISCUSSION}

If it is accepted that bone formation proceeds at a steady rate in laying hens, it is reasonable to assume that the extra hydroxyproline excreted on laying compared with non-laying days was derived largely from the collagen of the medullary bone that had been broken down during the calcification of the egg shell. This is supported by the data from the experiment in which four 6-hourly collections of urine were made during the egg-cycle. In this experiment, the peak levels of hydroxyproline occurred 6-I 8 hours after the start of shell formation, which is the period during which breakdown of medullary bone, as indicated by histological studies, is maximal (BLoom et al., I958). The Ca : hydroxyproline ratio of medullary bone is about 2o, more than twice that of cortical bone (AScENzI et al., I963), so that, if excretion of the hydroxyproline was quantitative, it would appear that, in these hens, approx. Ioo $\mathrm{mg}$ calcium per day was liberated from the skeleton during egg-shell formation as a result of bone resorption. This estimate represents a minimum value, since it is based on the assumption that all the hydroxyproline resulting from the degradation of collagen is excreted. This assumption may not be justified, however : Prockop (I964) estimated that only 5-ro p. Ioo of the hydroxyproline arising from the breakdown of insoluble collagen in young rats was excreted in the urine, but no estimates have been made for the hen, so that it is not possible to calculate the actual weight of bone that was resorbed in these experiments.

The mean level of urinary hydroxyproline on non-laying days was $1.70 \mathrm{mg} / \mathrm{kg}$ body weight, which is about twice that of an adult rat (LINDSTEDT and Prockop, I96I) and four times that in the adult human (calculated from the data of ANDFrson et al. (I965)). It is difficult to imagine that a level of hydroxyproline excretion of this magnitude at this time is reflecting skeletal breakdown, and it seems more probable that it is mainly a by-product of collagen synthesis.

The very large increase in the urinary excretion of acid phosphatase on laying, compared with non-laying days may be related to the increase in the plasma level of this enzyme that occurs during egg-shell formation (TAYLOR et al., I965). It has not 
been demonstrated that either the plasma or the urinary enzyme is of bone origin, although the circumstantial evidence is strong, since the activity of the enzyme has been shown to increase in a number of situations in which bone resorption is occurring, e. g. in the plasma of hens suffering from "cage-layer fatigue " (BELL and SILLER, I962), in the bones of rats treated with parathyroid hormone (VAES, I965), in cultures in which bone explants are resorbing under the influence of parathyroid hormone (SusI et al., I966) and in the plasma of laying hens fed a low-calcium diet (unpublished observations). The very large increase in the amount of acid phosphatase excreted in the urine on laying as opposed to non-laying days and the high correlation between the concentration of hydroxyproline and acid phosphatase in the urine are also consistent with the view that this acid hydrolase is released from the bone when resorption is occurring. The exact role of acid phosphatase in bone resorption is, however, obscure. It is possible that its release is incidental to the release of other lysosomal enzymes (e. g. acid protease, $\beta$-glucuronidase, $N$-acetyl- $\beta$-glucosaminidase) which have a known role in the breakdown of the organic matrix of bone.

\title{
SUMMARY
}

The excretion of hydroxyproline and acid phosphatase has been studied in 9 laying hens in relation to the calcification of the egg-shell. The mean weight of hydroxyproline excreted on laying days was $9 \mathrm{mg}$ and on non-laying days $4 \mathrm{mg}$. The level of acid phosphatase was four times greater on laying than on non-laying days, and there was a highly significant positive correlation between the $24 \mathrm{~h}$ excretions of hydroxyproline and acid phosphatase. These observations are discussed in relation to the role of the skeleton in egg-shell formation and to the mechanism of bone resorption.

\author{
RÉSUMÉ \\ EXCRÉTION URINAIRE D'HYDROXYPROLINE \\ ET DE PHOSPHATASE ACIDE \\ EN RELATION AVEC LA FORMATION DE LA COQUILLE DE L'CEUF \\ CHEZ LA POULE DOMESTIQUE
}

L'excrétion d'hydroxyproline et de phosphatase acide a été étudiée chez 9 pondeuses en relation avec la calcification de la coquille. La quantité moyenne d’hydroxyproline excrétée les jours de ponte est de $9 \mathrm{mg}$ alors qu'elle n'est que de $4 \mathrm{mg}$ les jours de pause. Le niveau de phosphatase acide est quatre fois plus important les jours de ponte que les jours de pause, et la corrélation entre l'excrétion journalière d'hydroxyproline et de phosphatase acide est positive et très hautement signi ficative. Ces observations sont discutées en relation avec le rôle du squelette dans la formation de la coquille et les mécanismes de la résorption osseuse.

\section{REFERENCES}

Anderson J., Bannister D. W., Tomlinson R. W. S., i965. Total urinary hydroxyproline excretion in normal human subjects. Clin. Sci., 29, 583-587.

Ascenzi A., Françors C., Bocciarelli D. S., I963. On the bone induced by aestrogens in birds. $J$. Ultrastruct. Res., 8, $491-505$.

Bell D. J., Siller W. G., 1962. Cage layer fatigue in Brown Leghorns. Res. vet. Sci., 3, 219-230.

Bergman I., Loxley R., I963. Two improved and simplified methods for the spectrophotometric determination of hydroxyproline. Anal. Chem., 35, 1961-1965. 
Bloom M. A., Domm L. V., Nalbandov A. V., Bloom W., I958. Medullary bone of laying chickens. Amer. J. Anat., 102, 4II-453.

Dull T. A., Henneman P. H., rg63. Urinary hydroxyptoline as an index of collagen turnover in bone. New Engl. J. Med., 268, 132*134.

Fussell M. H., I960. Collection of urine and fæces from the chicken. Nature (London), 185, $332-333$.

Krein L., Lafferty F. W., Pearson O. H., Curtiss P. H., I964. Correlation of urinary hydroxyproline, serum alkaline phosphatase and skeletal calcium turnover. Metabolism, 13, 272-284.

Lindstedt S., Prockop D. J., I96r. Isotopic studies on urinary hydroxyproline as evidence for rapidly catabolized forms of collagen in the young rat. J. biol. Chem., 236, I399-1403.

Prockop D. J., I964. Isotopic studies on collagen degradation and the urine excretion of hydroxyproline. J. clin. Invest., 43, 453-46o.

Simkiss K., I967. Calcium in reproductive physiology, p. 155-193. London, Chapman and Hall.

Susi F. R., Goldhaber P., Jennings J. M., rg66. Histochemical and biochemical study of acid phosphatase in resorbing bone in culture. Amer. J. Physiol., 211, 959-966.

TAYLOR T. G., VILLIAMS A., KIRKLEY J., I965. Cyclic changes in the activities of plasma acid and alkaline phosphatases during egg shell calcification in the domestic fowl. Canad. J. Biochem., 43, 45I457.

VAES G., I965. Excretion of acid and of lysosomal hydrolytic enzymes during bone resorption induced in tissue culture. Exp. Cell. Res., 39, 470-474.

ZifF M., Kibrick A., Dresner E., Gribetz H. J., 1965. Excretion of hydroxyproline in patients with rheumatic and non-rheumatic diseases. J. clin. Invest., 35, 579-587. 